\title{
EUROPEAN ORDER AND WORLD ORDER
}

$\mathrm{P}$ OLITICAL and Economic Planning (P.E.P.) has issued a readable but comprehensive pamphlet entitled "European Order and World Order". The principles on which the maintenance of Western civilization depends are summarized under four headings : freedom of thought, speech and movement; establishment of the rule of law both nationally and internationally; the progressive use of the State as an instrument of public welfare, not merely for policing or the protection of private interests ; and the organization of production and distribution to raise the standards of living and of life of all peoples. Compromise on, or surrender of, any of these essential values endangers the stability of our whole civilization. The central problem for Europeans is to make clear those principles, to see that our institutions and policies conform to them and to place behind them an overwhelming and enduring assembly of forces.

The success of the totalitarian challenge has been due largely to lack of clear thinking and moral courage in the democracies. It has scarcely been recognized that peaceful change, in both domestic and international affairs, depends upon extensive research and planning, so that problems aro seen and dealt with before they become chronic or acute, and before their reactions on other problems multiply. Technical and economic advances have made all countries so closely interdependent that the corresponding political advances can no longer be delayed.

While a crushing military defeat of Germany may not be necessary, it is vital that the basic principles of civilization represented by Great Britain and France should emerge triumphant. It has been necessary to reassert those principles in war because of recent failures to vindicate them in peace-failures which arose inevitably from the widespread attitude which insists on a complete divorce between economics and social needs, and at the same time has refused to face continuing after school age that blend of training and public propaganda known as education.

The fundamental task in reconstruction is to fill in these gaps in the use of economic power and of leisure, the existence of which has been exploited by extremist movements. Unless that is done, no political superstructure and no expression of ideals can save Western civilization from disintegration.

Much progress has recently been made towards tho establishment of world economic security, particularly in respect of the basic raw materials and foodstuffs. Wheat, beef, sugar, tea, whale-oil, rubber, tin, steel, aluminium and other commodities are already controlled on a world-wide or a European basis, although most of the schemes are still very young. These schemes require extension and improving by securing their joint control by consumer and producer interests, and providing buffer pools under disinterested management, and by making them accountable to an international supervisory authority, such as a Permanent Cartel Commission of the Ieague of Nations. Other steps in the same direction would be the establishment of international public utility corpora. tions, comparable with the Tennessee Valley Authority, for backward territories, and the provision of international machinery for rendering raw materials available on special terms for particular backward areas, victims of aggression, or in times of national disaster, etc. The creation of international mechanism for rural loans, grants-in-aid and price insurance schemes are other measures suggested to relievo the want and insecurity of primary producers.

The idea of a division of the world into industrial countries and a much larger group of colonial primary producing countries is mischievous, and industrial development of all countries within their economic limits should be encouraged. Finance should be subordinated to trado and economic development. Again, the systematic development of social services, accompanied by competent economic and financial policies, would be a porerful aid to world order and could greatly increase the productivity of peoples burdened with ill-health. In education, as in the organization of the creative uso of leisure or the development of colonies, there are large opportunities for international effort.

The logic of events in the economic and social fields is compelling an international approach and thereby inducing a reconsideration of the relation between nationalism and wider groupings. On the question of the federalization of Europe, the broadsheet touches but scantily, pointing out that our aim must be to create political forms out of which a fully developed federal system could easily emergo when the necessary degree of economic and political homo. geneity in Europe has been attained. The problem of European order can and should be isolated within the problem of world order. Settlement of the first would simplify settlement of the second, particularly as large areas in other continents are European dependencies.

The term European order in itself raises the question, what is Europe, whether it should include or not Great Britain or the U.S.S.R., for example. No treaty or political mechanism can provide substitutes for courage, foresight, intelligence and integrity, but it is important that the settlement after the war should both express and further the unity of European civilization by a suitable mechanism, by economic stimuli, by education and leadership.

The broadsheet accordingly proposes that the settlement should include not only provision for common institutions and common funds, but also the formulation in broad terms of the essential conditions of European civilization, backed by organized publicity, as strong and as effectively watched as the police arm. The establishment of a standing European Council in appropriate relation with the League might lead to a start in financial and economic affairs. It would involve, however, a common policing agency for Europe or part of it, and also a specific ngency for economic and social reconstruction, adequately financed. Many functions such as the improvement of communications, credit facilities, health services, education and research could be promoted more effectively by a European agency than by a host of national agencies. 